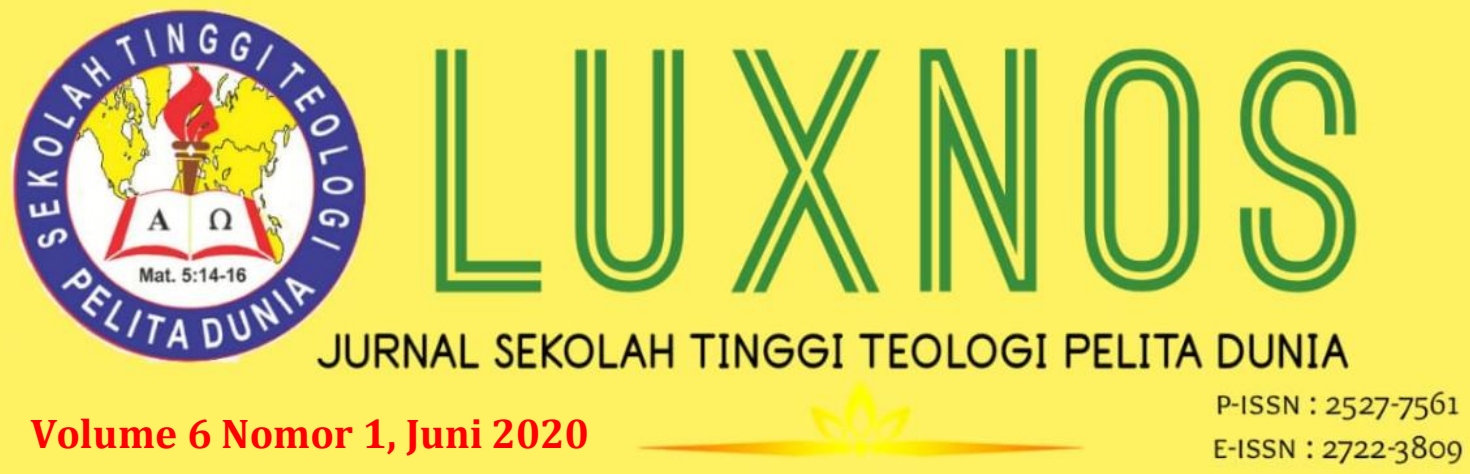

\title{
Studi Teologis terhadap Makna Ungkapan “Aku Adalah” (ego eimi) \\ Menurut Injil Yohanes
}

\author{
Gunar Sahari \\ Sekolah Tinggi Teologi Pelita Dunia Tangerang, gunar.sahari@gmail.com
}

\begin{abstract}
This research is a theological study of the meaning of the phrase Jesus "ego eimi" or "I am" which appears seven times in the Gospel of John. By using a qualitative approach specifically to the literature review, the meaning is obtained. Actually this phrase would emphasize two urgent things, namely: about the divinity of Jesus and about Jesus' mission in the world.
\end{abstract}

Keywords: Jesus, John, Ego Eimi.

Abstrak: Penelitian ini tentang studi teologis terhadap makna ungkapan Yesus "ego eimi" atau "Aku adalah" yang muncul tujuh kali dalam Injil Yohanes. Dengan menggunakan pendekatan kualitatif yang secara spesifik kepada kajian pustaka, maka diperolehlah maknanya. Sebenarnya ungkapan ini hendak menekankan dua hal yang urgen, yakni: tentang keilahian Yesus dan tentang misi Yesus di dunia.

Kata Kunci: Yesus, Yohanes, Ego Eimi.

\section{Pendahuluan}

Injil Yohanes dibedakan dari ketiga Injil lainnya (Matius, Markus, Lukas), oleh karena memang memiliki perspektif yang sedikit berbeda tentang Yesus. Hal itu terlihat jelas dengan prolog yang muncul pada pasal awal Injil ini dan sekaligus penulis injil ini sama sekali tidak mendeskripsikan tentang kelahiran Yesus. Mengapa bisa demikian?

Alasannya terlihat jelas ketika penulis Injil Yohanes menyatakan tujuannya untuk Injil yang ditulisnya dalam Yohanes 20:31, "Supaya kamu percaya bahwa Yesuslah 


\section{JURNAL LUXNOS \\ Volume 6 Nomor 1, Juni 2020}

Mesias, Anak Allah, dan supaya kamu oleh imanmu memperoleh hidup dalam nama-Nya." Menurut Bruce Milne,

"Kata Yunani untuk percaya dalam ayat itu dapat dinalar dengan cara lain. Bacaan tersebut mencerminkan kata kerja bentuk Yunani aoris, yang menunjukkan suatu tindakan percaya (Yunani: pisteusete). Menurut bacaan ini, maksud Yohanes adalah untuk menginjili; ia menulis untuk membangkitkan pengabdian yang teguh kepada Kristus. Pengertian lain yang juga mungkin berdasarkan bahasa aslinya: kata kerja Yunani untuk percaya dianggap sebagai bentuk present (Yunani: pisteuete). Itu berarti ini ditulis supaya mereka percaya akan terus-menerus percaya. Maksudnya, supaya mereka bertahan dalam iman mereka dan bertumbuh di dalamnya - memuridkan mereka yang telah percaya".1

Berdasarkan uraian dari Milne di atas, maka jelas sekali tendensi dari Injil ini adalah supaya setiap pembaca percaya bahwa Yesus adalah Mesias, Anak Allah yang hidup. Akan tetapi, apakah benar bahwa dalam mayoritas penjelasan Injil Yohanes hendak menunjukkan bahwa benar Yesus adalah Mesias? Menurut Leon Morris, "Ini adalah kitab mengenai Yesus. Hal ini diteguhkan oleh kenyataan bahwa Yohanes menggunakan nama Yesus sebanyak 237 kali, jauh lebih banyak dari kitab PB manapun... Perhatian Yesus tertuju sepenuhnya pada Yesus, dan biarpun benar bahwa ia memberi perhatian pada topik-topik lain, ia juga melihat segala-galanya dari segi pentingnya kedatangan Yesus ke dunia ini untuk hidup dan mati bagi kita".2 David Iman Santoso menambahkan bahwa, "Yohanes banyak sekali mengisahkan tema dan peristiwa yang berkenaan dengan person Yesus yaitu kemesiasan Yesus...".3 Menurut Andreas J. Kostenberger, "Yohanes kemungkinan besar menulis untuk bangsa Yahudi yang tidak mengakui Kristus sebagai Mesias dan kaum proselit... Yohanes tidak mungkin berhenti berusaha meyakinkan sesama bangsanya agar percaya teguh bahwa Yesus sebenarnya adalah Mesias dan tidak seorang pun dapat sampai kepada Bapa kalau tidak melalui (Dia), (14:6)".4

Dengan demikian, dapat dilihat bahwa penekanan utama dari Injil Yohanes adalah Yesus adalah Anak Allah. Dan melalui pemberitaan itu, setiap pembaca diharapkan dapat percaya dan menerimanya. Lalu, apakah ketika Yohanes memunculkan ungkapan "ego eimi" atau "Aku adalah" untuk menekankan Yesus sebagai Anak Allah? Hal inilah yang akan diteliti dalam penelitian ini. Apakah makna ungkapan "ego eimi" atau "Aku adalah"?

${ }^{1}$ Bruce Milne, Seri Pemahaman Dan Penerapan Amanat Alkitab Masa Kini: Yohanes (Lihatlah Rajamu!), (Jakarta: YKBK, 2010), hlm. 29.

${ }^{2}$ Leon Morris, Teologi Perjanjian Baru, (Malang: Gandum Mas, 2014), hlm. 311-312.

${ }^{3}$ David Iman Santoso, Theologi Yohanes: Intisari dan Aplikasinya, (Malang: SAAT, 2014), hlm. 33.

${ }^{4}$ Andreas J. Kostenberger, Encountering John: Injil dalam Perspektif Sejarah, Sastra dan Teologis, (Malang: SAAT, 2015), hlm. 27. 
dan bagaimana kemudian dapat menerapkannya dan mengimplementasikan dalam kehidupan praktis orang Kristen?

\section{Metode Penelitian}

Karena penelitian ini lebih fokus kepada penelitian kualitatif, maka akan lebih menitikberatkan pada studi dan kajian pustaka. Dengan menggunakan analisis biblis teologis untuk mencapai sebuah pemahaman yang benar guna diimplementasikan dalam kehidupan praktis.

\section{Hasil dan Pembahasan}

Apa makna ungkapan dari "Aku adalah" (ego eimi)? Kemudian bagaimana penerapannya dalam kehidupan praktis jemaat? Kedua pertanyaan inilah yang akan dijawab dalam penelitian ini. Menurut David Iman Santoso, "Dalam Injil Yohanes ada tujuh kali ucapan "Aku Adalah...” (ego eimi) yang diucapkan oleh Tuhan Yesus. Ucapanucapan ini termasuk unik, yang disebut emphatic pronoun, yaitu ada penakanan "Aku", yaitu Yesus, bukan orang lain yang mengatakan. Penekanan ini merupakan ciri penulisan Yohanes dan sekali lagi mempunyai makna Kristologis yang besar bagi person Kristus".5

Istilah Yunani "ego" adalah kata ganti orang pertama bentuk tunggal kasus nominative. Sedangkan istilah "eimi" adalah verba orang pertama tunggal kini aktif indikatif. Artinya kedua bentuk kata ini dapat dipisahkan dalam penggunaanya, misalnya kata "ego" sendiri mempunyai arti kata ganti orang pertama tunggal. Tetapi akan menjadi berbeda maknanya apabila kata "ego" dan "eimi" digunakan pola serangkai.

Pada LXX, kata Ego Eimi ini muncul ketika Tuhan menjawab pertanyaan Musa tentang siapa nama Allah (Kel. 3:14). Dan dengan memakai kata Aku adalah Aku. Kemudian dalam Injil Yohanes, istilah ini kembali dipakai oleh Yohanes. Mungkin saja hendak menegaskan bahwa Bapa (Yahwe) yang mempergunakan ungkapan Aku adalah Aku atau Ego Eimi dalam Perjanjian Lama ini dimunculkan oleh Yohanes dalam pengakuan Yesus dengan kalimat yang sama yaitu Ego Eimi. Artinya, Yesus sedang menunjukkan eksistensi-Nya sebagai Allah yang dikenal oleh orang Israel dalam Perjanjian Lama.6

Makna ungkapan Ego Eimi ini juga menunjukkan eksistensi Yesus yang adalah kekal, bukan hasil penciptaan atau ciptaan. Bandingkan dalam Yohanes 8:58, ungkapan

5 David Iman Santoso, hlm. 94.

6 Kata ini muncul pertama kalinya dalam Kitab Septuaginta untuk menerjemahkan pernyataan YHWH yang menyingkapkan nama-Nya pada Musa sbb: "Firman Tuhan kepada Musa: "AKU ADALAH AKU." Lagi firman-Nya: "Beginilah kaukatakan kepada orang Israel itu: AKULAH AKU telah mengutus aku kepadamu." Frasa "Aku adalah Aku" dalam bahasa Ibrani adalah Ehyeh asyer Ehyeh yang secara literal diterjemahkan dengan "Aku ada yang Aku ada". Dalam naskah Septuaginta (terjemahan TaNaKh dalam bahasa Yunani) diterjemahkan, Ego eimi ho on. (Sumber: http://betmidrash.blogspot.com/2017/02/makna-pernyataan-ego-eimi-oleh-yesus.html ) 
Ego Eimi kembali digunakan oleh Yesus ketika membandingkan diri-Nya dengan Abraham. Sebelum Abraham jadi maka Aku telah Ada. Ungkapan Aku telah ada merupakan terjemahan dari ungkapan Ego Eimi.

Pada Injil Yohanes, Yesus menggunakan bentuk Ego Eimi sebanyak 7 kali. Yesus mengatakan bahwa Dia adalah "Roti" (Yoh 6:35 "Ego eimi ho Artos"), "Terang Dunia" (Yoh 8:12, "Ego eimi to Phos tou kosmou"), "Pintu" (Yoh 10:7, "Ego eimi he Thura ton Probaton"),"Gembala" (Yoh 10:11, "Ego eimi ho Poimen ho Kalos") "Kebangkitan dan Hidup" (Yoh 11:25 "Ego eimi he Anastasis kai he Zoen"), "Jalan, Kebenaran, Hidup" (Yoh 14:6, "Ego eimi ho Hodos kai he Aletheia kai he Zoen"), "Anggur" (Yoh 15:1, "Ego eimi he Ampelos he alethine").

Donald Guthrie mengatakan perihal kemunculan ungkapan ego eimi pada tujuh kesempatan yang dikemukakan oleh Yesus untuk menunjuk kepada diri-Nya bahwa, “Melalui perkataan 'Aku adalah', Yesus membuat hal-hal yang masih abstrak dalam pendahuluan Injil menjadi nyata dalam pribadi. Hal ini menyangkut hidup, kebenaran dan juga terang. Yohanes memperlihatkan bahwa Yesus menyatakan diri sebagai perwujudan dari semua cita-cita tertinggi yang pernah dicari orang". 7 Ditambahkan oleh Guthrie, "Ego eimi di sini harus dilihat sebagai penghubung dengan nama untuk YHWH yang dinyatakan dalam Keluaran 3 dan dengan penggunaan tanpa tambahan dari 'Aku' (Ibr: "Ani Hu"/Yun: "Ego Eimi“) dalam Yesaya 46:4".8

Aku adalah Roti Hidup (6:35, 41,48,50-51). Ungkapan ini dikemukakan oleh Yesus dalam konteks ketika Dia memberi makan 5000 orang. Dari apa yang dikemukakan olehNya memberikan indikasi bahwa Yesus sebenarnya hendak menegaskan bahwa tanpa Dia tidak ada hidup yang sejati. Hal ini pun disetujui oleh David Iman Santoso. Bahkan Santoso menambahkan, "Oleh sebab itu, di samping Ia mengatakan "Akulah Roti Hidup", Ia juga mengatakan bahwa roti hidup adalah roti yang turun dari surga dan memberi hidup kepada dunia (6:33)".9

Aku adalah Terang Dunia $(8: 12 ; 9: 5)$. Ungkapan ini dikemukakan oleh Yesus dalam konteks ketika Dia menyembuhkan kebutaan seorang anak yang menderita kebutaan sejak lahir. Itulah sebabnya berdasarkan konteks ini, dapat dipahami bahwa melalui mukjizat ini dan kemudian dipertegas dengan ungkapan Aku adalah terang dunia, Yesus sebenarnya hendak menegaskan bahwa di luar Yesus manusia akan berada dalam kegelapan. Sehingga manusia tidak akan pernah dapat melihat dan mengenal yang namanya kebenaran.

Aku adalah Pintu $(10: 7,9)$. Santoso mengatakan, "Pintu adalah eksklusif sifatnya, yang berarti kita bisa berada di sebelah dalam atau sebelah luar. Dalam ajarannya tentang

7 Donald Guthrie, Teologi Perjanjian Baru 1, (Jakarta: BPK Gunung Mulia, 1993), hlm. 375.

8 Donald Guthrie, hlm. 375. Guthrie, Teologi Perjanjian Baru 1, 375

9 David Iman Santoso, hlm. 94. Santoso, Tafsiran Yohanes, 94. 
Dia sebagai gembala yang baik, Dia mengatakan bahwa Dia adalah pintu, yaitu pintu keselamatan, di mana Ia mengatakan "Akulah pintu, barangsiapa masuk melalui Aku, ia akan selamat..." (10:9)".10 Dari ungkapan bahwa tidak ada seorang pun dapat datang kepada Bapa kalau tidak melalui Aku, memberikan sebuah ajaran bahwa Yesus satusatunya jalan untuk dapat memiliki persekutuan dengan Bapa. Dan persekutuan itu akan berdampak kepada keselamatan atau kehidupan yang kekal.

Aku adalah Gembala yang Baik (10:11). Dalam konteks ini, Yesus sebenarnya sedang membedakan diri-Nya dari pencuri domba atau gembala yang palsu atau upahan. Seorang gembala upahan hanya melakukan tugasnya semata-mata profesi atau untuk sumber penghasilan, dan dia tidak akan pernah rela untuk berkorban apalagi mati untuk domba-domba yang digembalakannya. Berbeda halnya dengan Yesus, karena tujuan kedatangan-Nya ke dalam dunia memang untuk mati dan memberikan hidup-Nya bagi domba-domba-Nya, supaya mereka memiliki hidup. Menurut Santoso, "Ajaran Yesus sebagai gembala yang baik ini mempunyai relevansi yang besar dalam kehidupan bergereja".11

Aku adalah Kebangkitan dan Hidup (11:25). Ungkapan ini disampaikan oleh Yesus ketika Dia membangkitkan Lazarus dari kematian. Sehingga dapat memberikan sebuah pengajaran bahwa Yesus adalah kebangkitan dan hidup, dan Dia berkuasa atas maut, yang mana selanjutnya terbukti dengan peristiwa kebangkitan-Nya. Selain itu hal inipun hendak menegaskan bahwa di luar Yesus tidak mungkin ada hidup. Karena Dia adalah hidup dan sumber kehidupan.

Aku adalah Jalan, Kebenaran dan Hidup (14:6). Ketika Yesus mengatakan bahwa Dia adalah jalan, maka sebenarnya memiliki prinsip yang sama ketika Dia mengatakan bahwa Yesus adalah pintu. Sehingga dapat dipahami bahwa maksudnya adalah Yesus merupakan pintu atau jalan keselamatan. Di mana melaluinya, setiap manusia dapat mengenal kebenaran dan memperoleh hidup yang kekal.

Selanjutnya kebenaran dalam konteks ini merujuk kepada kebenaran Injil. Mengapa bisa? Karena Injil adalah Yesus itu sendiri. Itulah sebabnya, seseorang yang memberitakan Injil harus memberitakan Yesus, tentunya Yesus seperti yang disampaikan oleh Alkitab, yaitu: Yesus yang telah berinkarnasi, menderita, mati, dan bangkit. Santoso mengatakan, "Apabila Yesus mengatakan bahwa Ia adalah kebenaran, berarti bahwa Yesus is absolutely realible".12

Kemudian hidup dalam konteks ini pastinya adalah kehidupan kekal, yang akan diterima dan dimiliki oleh setiap orang yang percaya kepada Yesus. Mereka tidak akan binasa, melainkan akan memperoleh hidup yang kekal di dalam Kristus.

\footnotetext{
${ }^{10}$ David Iman Santoso, hlm. 95.

${ }^{11}$ David Iman Santoso, hlm. 96-97.

12 David Iman Santoso, hlm. 98.
} 
Aku adalah Pokok Anggur yang Benar (15:1, 5). Apabila membaca Alkitab (khususnya PL), maka dari sana dapat dipelajari tentang bangsa Israel yang disebut sebagai pokok anggur yang gagal dan tidak percaya (bdk. Maz. 80:8-16; Yes. 5:1-7; Yer. 2:21; Yeh. 15; 19:10-14; Hos. 10:1). Berdasarkan inilah kemudian kita dapat memahami ungkapan Yesus, "Aku adalah pokok anggur yang benar". Kata Yunani yang digunakan di sini menunjuk kepada kebenaran yang sesungguhnya, atau lawan dari palsu. Sehingga dapat dipahami bahwa Yesus adalah pokok anggur yang sebenarnya, yang sejati; di mana setiap orang Kristen dapat bertumbuh dan mengenal Bapa.

Itulah sebabnya, karena Yesus adalah pokok anggur yang benar, maka kita sebagai rantingnya wajib tinggal dan berbuah di dalamnya. Dan hanya dengan pokok anggur yang benar, kita dapat hidup dan berbuah lebat.

Berdasarkan pembahasan di atas, maka berikut ini akan dikemukakan beberapa hasil penelitian yang diperoleh, yakni:

1. Melalui ungkapan ego eimi, Yesus sebenarnya hendak menunjukkan siapa Dia sebenarnya. Dalam hal ini Yesus hendak menegaskan bahwa Dia adalah Allah yang sehakikat dengan Bapa, seperti yang telah dikenal dalam PL.

2. Melalui ungkapan ini juga, Yesus hendak menegaskan misi-Nya berinkarnasi menjadi manusia. Itulah terlihat jelas dalam tujuh ungkapan "Aku adalah" dalam Injil Yohanes. Di mana ketujuhnya hendak menegaskan bahwa melalui Dia, setiap manusia akan memperoleh hidup kekal dan dapat memiliki persekutuan dengan Bapa.

\section{Kesimpulan}

Dengan demikian, setelah melalui studi teologis terhadap ungkapan "ego eimi" maka dilihat dengan jelas betapa ungkapan ini sangat teknis dan memiliki makna teologis khususnya kristologis yang sangat kuat. Karena dengan tegas Yesus melalui ungkapan ini hendak menegaskan tentang keilahian-Nya.

\section{Referensi}

Milne, Bruce, Seri Pemahaman Dan Penerapan Amanat Alkitab Masa Kini: Yohanes (Lihatlah Rajamu!), Jakarta: YKBK, 2010.

Morris, Leon, Teologi Perjanjian Baru, Malang: Gandum Mas, 2014.

Santoso, David Iman, Theologi Yohanes: Intisari dan Aplikasinya, Malang: SAAT, 2014.

Kostenberger, Andreas J., Encountering John: Injil dalam Perspektif Sejarah, Sastra dan Teologis, Malang: SAAT, 2015.

Guthrie, Donald, Teologi Perjanjian Baru 1, Jakarta: BPK Gunung Mulia, 1993. 


\section{JURNAL LUXNOS}

Volume 6 Nomor 1, Juni 2020

http://bet-midrash.blogspot.com/2017/02/makna-pernyataan-ego-eimi-oleh yesus.html ). 